\title{
Empowering Small Businesses of Pearl Farming
}

\author{
Zoel Hutabarat ${ }^{1}$ \\ \{zoel.hutabarat@uph.edu ${ }^{1}$ \} \\ ${ }^{1}$ Doctoral Program Strategic Management, Universitas Trisakti, Jl. MH Thamrin Boulevard 1100, Kelapa \\ Dua, Karawaci, Indonesia \\ ${ }^{1}$ Business School, Universitas Pelita Harapan, Indonesia
}

\begin{abstract}
The production and export growth of seawater pearls from West Papua each year is quite large, even including the top five in the area that produces sea pearls from Indonesia. However, the growth of production and export is not accompanied by an increase in the welfare of the people or fishermen who cultivate the pearl of seawater. This research would like to see how fishermen cultivated sea water pearls who are seen as micro business owners, live their business life where when we look at their business, they should be able to live well and run their business well. The results show that the empowerment efforts of both local government and private involvement have not been well targeted and the absorption of knowledge of micro, small and medium enterprises owners in the Raja Ampat area is still weak so that the purpose of empowering micro, small and medium enterprises is difficult to achieve. The pattern of empowerment and time of program implementation is one of the obstacles of the implementers of the empowerment.
\end{abstract}

Keywords: Community empowerment, government and private sector, corporate social responsibility, absorptive capacity

\section{Introduction}

Pearl is one of the raw materials of jewelry, produced from Indonesia natural resources. One of the largest pearl producing regions in Indonesia is West Papua or more precisely in the Raja Ampat tourist area, which averages production of one million grams per year from 2013 to 2016. West Papua's ability to produce world-class pearls in large quantities not followed by the growth of the welfare of the fishermen who cultivated the pearls. There are still many people who work as fishermen pearl lovers have not been able to meet the survival rate of their families when the price of pearls produced is not cheap. One pearl with an average weight of two grams, the cheapest is priced at up to two hundred thousand rupiah per item. From simple calculations can be seen the income earned by the cultivated fish pearls is actually quite large. But their ignorance in managing finances and the thought of saving is still very minimal, often make them always in a state of deprivation. Several Pelita Harapan University students from Sorong feel moved to be able to help equip the fishing community so that their life can be better through several activities and corporate social responsibility programs to companies operating in West Papua region.

Papua land, Indonesia's easternmost region, has a variety of quality natural resources, both from the produce and the natural conditions that produce beautiful scenery. This extraordinary natural resource should be able to make a significant contribution to the life of the people of Papua in general. But in reality the economic condition of the people of Papua is uneven. There are still many Papuan people who are below the poverty line. This can also be seen in the people of West Papua, especially in the Raja Ampat tourist area. This area is one of the best and largest sea water producer regions in the world. Pearls originating from Indonesia 
known as the south sea pearl or queen of pearls, famous for the quality that can be accepted by the world market. This can be seen from the growth of Indonesian pearl exports which are included in the top 10 in the world.

Table 1. Exports Indonesian sea water pearl to the world (thousand US dollars)

\begin{tabular}{llllll}
\hline No Exporters & $\mathbf{2 0 1 3}$ & $\mathbf{2 0 1 4}$ & $\mathbf{2 0 1 5}$ & $\mathbf{2 0 1 6}$ \\
\hline & World & $2,456,566$ & $2,243,288$ & $2,117,992$ & $2,599,048$ \\
\hline 1 & Hong Kong, China & 609,282 & $1,164,065$ & $1,401,462$ & $1,812,326$ \\
\hline 2 & Japan & 194,933 & 234,317 & 266,988 & 282,572 \\
\hline 3 & French Polynesia & 86,635 & 96,660 & 69,260 & 111,387 \\
\hline 4 & Australia & 142,432 & 122,316 & 56,079 & 73,037 \\
\hline 5 & China & 189,665 & 122,326 & 98,115 & 67,798 \\
\hline 6 & Indonesia & 25,822 & 28,740 & 31,201 & 45,293 \\
\hline
\end{tabular}

Source: www.trademap.org

Table 2. Production of pearls per province in 2013-2015 (gram)

\begin{tabular}{|c|c|c|c|c|}
\hline \multicolumn{2}{|c|}{ No Province } & 2013 & 2014 & 2015 \\
\hline 1 & Bali & 162,000 & 184,885 & 679,075 \\
\hline 2 & Nusa Tenggara Barat & 732,162 & 850,879 & 850,979 \\
\hline 3 & Nusa Tenggara Timur & 50,000 & 80,247 & 258,634 \\
\hline 4 & Sulawesi Tenggara & 310,000 & 240,000 & 246,000 \\
\hline 5 & Maluku & - & - & - \\
\hline 6 & Maluku Utara & - & 57,872 & 50,800 \\
\hline 7 & Papua Barat & $1,075,937$ & 700,062 & 780,000 \\
\hline 8 & Others & 107,475 & 70,079 & 261,489 \\
\hline & Total & $2,437,574$ & $2,184,024$ & $3,127,039$ \\
\hline
\end{tabular}

From the above table can be seen sea pearl production produced by Indonesia and its contribution to the world sea pearl needs. The data shows the number of world exports in the form of sea water pearls and freshwater pearls. For freshwater pearls are dominated by China but for sea water pearls, Indonesia is still one of the largest contributors to the needs of the world. From the following table, the pearl water production table per province in Indonesia shows that the province of West Papua is able to contribute big enough for Indonesia.

A considerable amount of pearl production from West Papua should be followed by economic growth and the welfare of its people. With a simple calculation, the selling value of sea water pearls that on average weighs 2 grams per grain can be sold at a minimum of two hundred thousand rupiah. Can be seen the value of pearl production for the lowest quality only shows the value of the transaction amounted to 78 billion rupiah, the value is not small. But still the economic life of the people of West Papua, especially the fishing community of pearl cultivation does not necessarily become prosperous. In fact there are still many who are below the poverty line.

Table 3. Level of Education in West Papua

$2013 \quad 2014 \quad 2015 \quad 2016$

Not pass Elementary School 20,48\% 21,86\% 18,54\% 14,70\%

Elementary School $19,33 \% 19,16 \% 20,94 \% 21,63 \%$




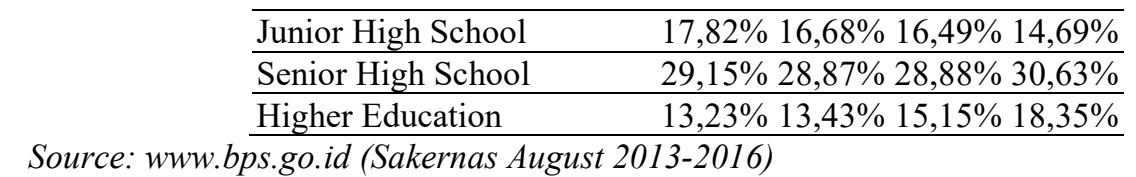

The level of education and culture is often made a scapegoat of the emergence of economic inequality and a considerable gap between indigenous Papuans and migrants, especially foreign companies operating in Papua. From the picture above can be seen also that there are still many people of West Papua who have not received education to high school even college of 51.02 percent of the population. It also describes the quality of workers who are mostly only educated up to junior high. Imagine the quality of work that can be generated and how knowledge they gain to develop themselves and the business they want to run.

Some students of Pelita Harapan University from Sorong, West Papua feel burdened to be able to improve the education and welfare of the people of West Papua, especially the pearl aquaculture fishermen in the Raja Ampat tourist area. For this reason, this research is done to see what pattern or method can be accepted by the society so that the education and prosperity level of the people of West Papua, especially Raja Ampat Regency can be improved.

\section{Literature Review}

\subsection{Framework for community empowerment and rural development}

Community empowerment is closely linked to social inclusion. Empowerment generally focuses on the individual level while social inclusion addresses the system or institutional level. Social inclusion is seen as one way of overcoming institutional constraints and improving the policy structure to help the poor and other marginalized groups to access assets and opportunities for development (Bennet 2002). The current international development agency focuses on participatory bottom-up community development strategies from the bottom up, and shifts their emphasis from the context of centralized development to society. Empowerment is perceived as the power to do something individually or collectively. Empowerment is the source to put pressure on institutions and policymakers to reform policies that affect quality of life. Empowerment enables the poor to overcome obstacles and open access to new livelihood opportunities (Saegaert, 2006). To accommodate the decentralized approach of marginalized communities to improve service delivery to the local level (Salmon 2007; Roche 2010). It is assumed that such community-based and participatory initiatives will help citizens improve their capacity for collective action that can produce significant development outcomes such as access to basic needs, improved quality of life and decreased social exclusion and inequality (Gutberlet 2009).

\subsection{Community empowerment}

Empowerment has been defined in many disciplines in various ways. The literature reiterates that community involvement in the development process greatly helps to increase the social impact on development actors and is considered a source of capacity building for local communities (Corbett and Keller 2004; Hjorth 2003; Wallerstein 2006; Terry et al., 2011). Speer et al. (2001) describes the empowerment process as an international sustainable process centered on the local community, involving collaborative and mutual efforts to gain control over resources and information. Bennet (2002) reported empowerment as a tool to increase the capacity and assets of local communities (individuals and groups). Improvements 
in community capacity not only helps to involve the community in the development process, but also the source to influence the decisions of local institutions that affect their lives. At the individual level, there are three components of empowerment processes undertaken together to improve capacity and skills, local resource management and participation in decision making (Schulz et al. 1995; Zimmerman 2000).

Empowerment is not a static experience, but a continuous and sustainable process. Capacity building helps communities to manage local resources based on self-help. Laverack (2001) reported three elements of empowerment. These elements are community participation, local organizational capacity and accountability. He further illustrates that there is a relationship between empowerment, participation and leadership. In the context of social policy, empowerment is the source to provide opportunities for people to participate while participation allows people empowered to take action that increases their quality of life (Sidorenko 2006). Results of empowerment can be manipulated on project completion and may influence policy makers' decisions including economics, $1238 \mathrm{M}$. M. Ahmad, N. B. Abu Talib political and institutional decisions. Empowerment is the source to counter all factors that directly or indirectly affect people's lives. Similarly, Alsop and Heinsohn (2005) illustrate that empowerment is a process that increases the capacity of individuals or groups so that they can make their own choices and change the desired choices into profitable actions and outcomes. Capacity building is a fundamental requirement for making effective choices. The extent of empowerment varies with the situation and depends on the availability, usage and achievement of options. Furthermore, community empowerment is not an individual act, it requires the act of community gathering and the equal involvement of all members of society. As Narayan and Petesch (2002) illustrate, a community is considered empowered if they participate in decision-making activities, have the capacity and resources to meet unmet needs and have access to timely and understandable information. The next section highlighting each component and its contribution to rural development.

\subsection{Absorptive capacity}

The concept of knowledge absorption proves to be flexible enough to be used in various fields of research. Most absorptive capacity is used in large companies, industrial organizations, strategic management, international business and technology management (Zahra and George, 2002). Absorptive capacity is used by researchers and business actors in various cases to identify, assimilate and exploit knowledge from environment (Cohen and Levinthal, 1989; p.569). Zahra and George (2002) propose the dimensions present in absorptive capacity into four dimensions. Previous Cohen and Levinthal (1989) only divides absorptive capacity into three parts: identify, assimilate, and exploit knowledge from environment. The four dimensions of absorptive capacity of Zahra and George (2002) were redefined by Fosfuri and Tribo (2006) to be: Acquisition, the ability to identify existing information in the environment around the company. This step is to know the information in circulation and validate the information in circulation and know the source of the information so it can be accounted for; Assimilation, the process by which a company uses information obtained from outside the company for analysis, interpretation and attempts to understand its use; Transformation, the ability to modify, adapt the external information and combine and combine such information with information within the company to generate information or even new knowledge for the company; Exploitation, the ability to utilize the information gained to be used as a competitive advantage of the company. 


\subsection{Education}

The level of education has an enormous influence on the knowledge possessed by a person, especially the business owner, to add managerial capabilities that are useful for the growth of his business (Honig, 1998; Kim et al., 2006; West and Noel, 2009). Education here is divided into two types: (1) education appropriate to industry needs and (2) business education in general. Education that suits industry or vocational needs relates to specific skills, insights and skills that can be applied to sectors, industries or markets. Business knowledge is generally intended to prepare a person to manage a company or handle a project.

The positive influence on performance (Deakin et al, 2005) is in line with the imagination, discovery, flexibility, and adaptability and minimal accumulation of knowledge and environments that can be built through education (Haber and Reicgel, 2005), in accordance with the size of the effort built (Lee and Tsang, 2001). As mentioned by Ramachandran and Kedia Shah (1999) and Veciana et al. (2005), university education plays an important role in the formation of companies that influence also the development of new schools to provide entrepreneurship education in university education.

\section{Conceptual Model}

This conceptual model is a causal relationship used in research or relationship logic to identify problems. This research will examine the relationship between the capability of the pearl collecting community in West Papua to the welfare of their lives through the empowerment of government and private parties.

The main focus of this study is to look at the effectiveness of empowering the small pearl business community in West Papua and its relationship with the ability of people to absorb Papuans in accordance with their education level. In addition to the level of formal education, this study also sees the empirical experience of these business actors, whether contributing to their expertise in the field and being able to bring prosperity to their lives or not.

\section{Conclusion}

This study emphasizes on proving previous research that looks at the relationship of government involvement in entrepreneurship development at the rural level in Pakistan and other areas. Are the findings of this study the same as those found previously? Or there are other factors that support the previous findings. This study tries to look at other factors that support the development of small business entrepreneurship in Papua so that the Indonesian people can grow and equally wellbeing. It is hoped that the findings in this study can be emulated and applied in other areas.

\section{References}

[1] Antara News. (2013). Raja Ampat, Bukti Keberhasilan KKP Padukan Konservasi, Pariwisata, dan Ekonomi. (P. Wire, Editor) Diakses 02 Oktober 2017 Antara news: http://www.antaranews.com/berita/371740/raja-ampat-bukti-keberhasilan-kkppadukan-konservasi-pariwisata-dan-ekonomi

[2] Aziliya, D. (2017). 2016, Industri Perhiasan Tumbuh 13\%. (B. C. Nursyifani, Editor) diakses $\quad 19 \quad$ Oktober 2017 Industri Bisnis: http://industri.bisnis.com/read/20170220/257/630114/2016-industri-perhiasan-tumbuh$13-$ 
[3] BALA, Z. T. (2015). Manokwari Tambah Uang Lauk Pauk dan Tunjangan Penghasilan PNS. Diakses 13 November 2017 Cahya Papua: http://www.cahayapapua.com/manokwari-tambah-uang-lauk-pauk-dan-tunjanganpenghasilan-pns/

[4] Bank Indonesia. (2014). Dinamika Perekonomian Global. Diakses 18 Desember, 2017 Bank Indonesia: http://www.bi.go.id/id/publikasi/laporantahunan/perekonomian/Documents/LPI\%2020 13\%20ID\%20-\%20Bagian\%20I\%20Perekonomian\%20Global.pdf

[5] Belch, G. E. Adverstising and Promotion. San Diego: Mc Graw Hill Education., 2015

[6] Billy, A. T. (2017). Perusahaan Mutiara di Indonesia Berkurang Drastis. diakses 12 Desember $2017 \quad$ Tribunnews: http://www.tribunnews.com/bisnis/2017/02/08/perusahaan-mutiara-di-indonesiaberkurang-drastis

[7] Endarwati, O. (2017). Industri Perhiasan Indonesia Tumbuh 13\% di 2016. Diakses 17 Oktober 2017 Sindonews: https:/ekbis.sindonews.com/read/1181690/34/industriperhiasan-indonesia-tumbuh-13-di-2016-1487593810.Harvard Review. University. HBR's Must-Reads on Strategy, 25., 2008

[8] Hidayat, F. (2017). Sandiaga Buka Pameran Mutiara di Lippo Mall Kemang. Diakses 10 Desember 2017 Berita Satu: http://www.beritasatu.com/jakarta/462431-sandiagabuka-pameran-mutiara-di-lippo-mall-kemang.html

[9] Irianto, A. (2013). Ekspor Mutiara Indonesia Terus Merosot. Diakses 03 November 2017 from Tempo: https://bisnis.tempo.co/read/462433/ekspor-mutiara-indonesiaterus-merosot

[10] Ishak, N. N. (2016). Indonesia South Pearl. (Sugiarti, Editor) Diakses 02 Oktober 2017 Trade with Remarkable Indonesia: http://djpen.kemendag.go.id/app_frontend/admin/docs/publication/6651482466378.pdf

[11] Jakarta, K. (2017). Industri Perhiasan Terus Tumbuh. Diakses 20 Desember 2017 Koran-Jakarta.com: http://www.koran-jakarta.com/industri-perhiasan-terus-tumbuh/

[12] Kementrian Kelautan dan Perikanan. (2017). Optimalkan Potensi Laut Indonesia Lewat Budidaya Kerang Mutiara. Diakses 17 Oktober 2017 Kementrian Kelautan dan Perikanan: http://news.kkp.go.id/index.php/optimalkan-potensi-laut-indonesia-lewatbudidaya-kerang-mutiara/

[13] Kotler, $\mathrm{P}$ and Gary Amstrong. Principles of Marketing. Fifteenth Edition: Pearson.,2014.

[14] Kimmel, Weygandt and Donald Kieso. Financial Accounting: IFRS Edition $2 e$. Hoboken: John Wiley \& Sons, Inc., 2013.

[15] Kurnia, D. (2017). Indonesia Ingin Buka Pasar Baru untuk Ekspor Perhiasan. Diakses 18 Desember 2017 Republika: http://nasional.republika.co.id/berita/nasional/daerah/17/10/26/oyfpsi284-indonesiaingin-buka-pasar-baru-untuk-ekspor-perhiasan

[16] Hansen, Mowen and Dan L. Heitger. Cornerstones of Managerial Accounting, 6th. Boston: Cengage Learning., 2016.

[17] Porter.M.E.. The five competitive forces that shape strategy. Harvard Business Review , 57, 57-71., 2008

[18] Rosalina. (2013). Ekspor Mutiara Indonesia Terus Merosot. Diakses 30 November 2017 Tempo Co: https://bisnis.tempo.co/read/462433/ekspor-mutiara-indonesia-terusmerosot 
[19] Senja, A. M. (2017). Beli Perhiasan Mutiara Bisa Dijadikan Investasi? Retrieved 02 November 2017 Tribunnews: http://www.tribunnews.com/bisnis/2017/03/16/beliperhiasan-mutiara-bisa-dijadikan-investasi

[20] Strack, E. (2006). Pearl. Sydney: Kunz \& Stevenson Publisher.

[21] Taylor, J. a. Pearl Production. Amsterdam: Southgate P.C and Lucas J.S. The Pearls Pyster., 2008

[22] Trade Map. Market Analysis and Research. Geneva: nternational Trade Centre (ITC)., 2017

[23] Yasmin, P. A. (2017). KKP Cek Mutiara China Masuk RI Pakai Kode Produk Manikmanik. Diakses 27 November 2017 Detik Finance: https://finance.detik.com/beritaekonomi-bisnis/3725084/kkp-cek-mutiara-china-masuk-ri-pakai-kode-produk-manikmanik

[24] Yud. (2013). Indonesia Pemasok Terbesar Mutiara Laut Dunia. (Yud, Editor) diakses 04 Oktober 2017 Berita Satu: http://www.beritasatu.com/ekonomi/136906-indonesiapemasok-terbesar-mutiara-laut-dunia.html 